\title{
Recreational angling as a pathway for invasive non-native species spread: awareness of biosecurity and the risk of long distance movement into Great Britain
}

\author{
E. R. C. Smith $(\mathbb{D} \cdot$ H. Bennion $\cdot$ C. D. Sayer $\cdot$ D. C. Aldridge $\cdot$ M. Owen
}

Received: 28 August 2018/ Accepted: 3 December 2019/Published online: 9 January 2020

(C) The Author(s) 2020

\begin{abstract}
Identifying and establishing the relative importance of different anthropogenic pathways of invasive non-native species (INNS) introduction is critical for effective management of their establishment and spread in the long-term. Angling has been identified as one of these pathways. An online survey of 680 British anglers was conducted to establish patterns of movement by British anglers abroad, and to establish their awareness and use of biosecurity practices. The survey revealed that $44 \%$ of British anglers travelled abroad for fishing, visiting 72 different countries. France was the most frequently visited country, accounting for one-third of all trips abroad. The estimated time taken to travel from Western Europe into Great Britain (GB) is within the time frame that INNS have been shown to survive on damp angling equipment. Without biosecurity, it is therefore highly likely that INNS could be unintentionally transported into GB on damp angling gear.
\end{abstract}

E. R. C. Smith $(\bowtie) \cdot$ H. Bennion · C. D. Sayer

Environmental Change Research Centre, University

College London, Pearson Building Gower Street, London,

UK

e-mail: emily.r.smith@ucl.ac.uk

D. C. Aldridge

Department of Zoology, University of Cambridge,

Cambridge, UK

M. Owen

Angling Trust, Eastwood House, 6 Rainbow Street,

Leominster, UK
Since the launch of the Check, Clean Dry biosecurity campaign in GB in 2011, the number of anglers cleaning their equipment after every trip has increased by $15 \%$, and $80 \%$ of anglers now undertake some form of biosecurity. However, a significant proportion of the angling population is still not implementing sufficient, or the correct biosecurity measures to minimize the risk of INNS dispersal on damp angling equipment. With the increase in movement of anglers abroad for fishing, further work is required to establish the potential for INNS introduction through this pathway.

Keywords Angling - Biosecurity · Awareness · Invasive species $\cdot$ Human pathways

\section{Introduction}

Introduction of non-native species by human-mediated jump dispersal is well documented and encapsulates a variety of activity, from the unintentional harbouring of non-native species within shipping cargo (Suarez et al. 2001) to intentionally introducing species for economic purposes such as aquaculture in the case of the Signal crayfish (Pacifastacus leniusculus) (Holdich et al. 2004). Although many anthropogenic jump dispersal mechanisms or 'pathways' have been identified (Hulme 2009), the relative 
importance of each pathway is unknown. Related to this, is the increasing recognition that, for many invasive non-native species (INNS) the most costeffective approach to minimising their environmental and socio-economic impacts is prevention of initial establishment in the first place (Leung et al. 2002; Finnoff et al. 2007; Caplat and Coutts 2011; Brundu 2015). Once an INNS is introduced, unless it is detected early and rapid eradication is undertaken, it often becomes highly expensive, and in some cases impossible to completely eradicate (Mack et al. 2000; Kolar and Lodge 2001; Wittenberg and Cock 2001; Simberloff et al. 2013). Recognising the long-term economic and environmental benefits of preventing further INNS invasions, prevention has been placed at the forefront of the EU Regulation of Invasive Alien Species (1143/2014) (Beninde et al. 2014). Following the introduction of this regulation it is now an obligation for EU Member States to investigate and prioritise potential pathways of human INNS introduction (Trouwborst 2015). An INNS pathway refers to a suite of processes or human activities, that result in the intentional or unintentional movement of an INNS from its natural range, either past or present, into a new environment (Genovesi and Shine 2004; Pyšek et al. 2011). Vectors are distinguished as the physical means or agent such as a ship, vehicle wheels or angling net, via which INNS are moved outside their native range. Through the creation of pathway action plans (PAPs), resources can be allocated to target the most significant pathways, or a particular aspect of a vector identified as the weakest link or greatest biosecurity threat. Managing pathways of human introduction represents a more effective approach than individual INNS management as it reduces the risks of all nonnative species using that pathway. This is particularly important as the dispersal mechanisms of many nonnative species remain uncertain, and due to time lags it is hard to predict which non-native species may, or may not become invasive in the future (Essl et al. 2015).

Recreational angling has been identified in the EU Regulation and the convention on biological diversity (CBD) as a potential human pathway of INNS introduction (Hulme 2009; Harrower et al. 2018). Used traditionally for the provision of food, angling has also evolved into a popular catch-and-release sport in Western countries, with a rod and line used to catch a variety of fish species (Von Brandt 1964; Pitcher and
Hollingworth 2002). Grouped together with aquaculture and other leisure activities, angling has been reported to account for more than $40 \%$ of aquatic INNS invasions in Europe (DAISIE 2009). Angling is a highly popular activity, with an estimated $11.7 \%$ and $4.8-6.5 \%$ of the population in the United States and Europe participating in fishing every year (Hickley 2018). Around 9\% of the population in England and Wales aged 12 years or older took part in angling in 2009-2010, equating to around 4.2 million people (Simpson and Mawle 2010; Sports England 2011). However, despite the link between angling and nonnative species being reported for many years (Maitland 1987; Winfield et al. 1996; William and Moss 2001; Zięba et al. 2010) the relative importance of angling as a pathway and vector for non-native species dispersal is still relatively unknown. A few studies have been undertaken to investigate the role of angling in the secondary dispersal of INNS between water bodies (Gates et al. 2009; Anderson et al. 2014), and others have reported the potential for INNS introduction and spread from the use of live bait by anglers (Keller et al. 2007; Kilian et al. 2012; Drake and Mandrak 2014; Cerri et al. 2017). In North America, higher numbers of non-native species have also been found to coincide with areas of greater recreational fishing demand (Davis and Darling 2017). However, there have been limited, if any, studies undertaken to investigate the potential for long-distance jump dispersal of INNS between continents/countries on damp angling equipment. This is despite a recent increase in the number of tourists travelling abroad for recreational activities including angling (Hulme 2015).

Many INNS can survive for a few days (Stebbing et al. 2011; Bacela-Spychalska et al. 2013) and in some cases up to two weeks in damp angling equipment and clothing (Fielding 2011; Anderson et al. 2015). In 2011 around 64\% of British anglers stated that they fished in more than one catchment per fortnight (Anderson et al. 2014). The high frequency of anglers returning from fishing within the time frame of INNS persistence in damp equipment suggests that angling gear could act as vector for the spread of INNS between waterbodies. Thus, mechanisms need to be implemented to ensure any invasive species present on equipment are removed or killed before re-use. Recognising this, the biosecurity campaign check, clean, dry (CCD) was launched in Great Britain by Defra in 2011. Biosecurity refers to the undertaking of 
a set of measures which individually, or collectively, contribute to a reduction in the risk of spreading INNS, including plants, animals and microbes (Dobson et al. 2013; Shannon et al. 2018). The aim of the CCD campaign is to provide simple biosecurity guidance to recreational water users in order to increase awareness of INNS and in turn to minimise their spread. There are further measures that complement the CCD including strategic planning to ensure sites without INNS are visited prior to sites with known INNS populations, and/or rotating different sets of equipment between sites (Dunn and Hatcher 2015). By preventing the spread of INNS in the first place, it may save substantial environmental and economic costs in the long-term due to damage to the environment, and expenses to remove INNS.

Public engagement and compliance will be essential for the success of this biosecurity campaign (Bremner and Park 2007; Garcia-Llorente et al. 2008; Gozlan et al. 2013). People are often the weakest leak in the control of INNS species (Cliff and Campbell 2012) and it can take time for individuals to adopt biosecurity measures as a new social norm (Rogers 2003; Prinbeck et al. 2011; Sutcliffe et al. 2018). Consequently, monitoring the uptake of biosecurity by recreational users is essential to assess the success of the campaign and to identify future priorities. However, except for a baseline study conducted during the first year of the CCD launch (Anderson et al. 2014), changes in the biosecurity behaviour of recreational water users including British anglers is unknown. This study explores changes in angling biosecurity behaviour since the launch of the CCD campaign, and assesses the risk of recreational angling activity unintentionally introducing, or spreading, non-native species into Great Britain (GB) from abroad on damp angling equipment (boots, nets). We focus on the dispersal of INNS species potentially transmitted in angling equipment such as macrophytes and macroinvertebrates. Although parasites and diseases such as the Salmon louse (Gyrodactylus salaris) are not explicitly investigated, there is also potential for dispersal of these in contaminated angling equipment (Peeler et al. 2004).

\section{Methodology}

A structured online questionnaire survey was conducted between the 8th of July and 31st of October
2015. The survey was produced using the online software, SurveyMonkey. The use of the internet for data collection is accepted as an effective approach to data collection, providing access to a geographically dispersed population, and a sampling size not always achievable using an interview-based approach (Couper et al. 2007; Couper and Miller 2008). The questionnaire was publicised to anglers by Angling Trust social media (Facebook and Twitter) and also circulated via email to their members. The Angling Trust is an organisation that represents all game, coarse and sea anglers in England and Wales on environmental and angling issues. As a result, there is potential for a high response from anglers that have an interest in the natural environment as they are more likely to engage with Angling Trust ideas. To account for this, the questionnaire was also circulated to angling clubs, relevant angling magazines, and promoted at three GB angling events. This included two regional angling forums which brought together angling clubs in the southwest and southeast of England, and the Country Land and Business Association (CLA) game fair in northern England. The CLA is a membership organisation for owners of land, property and business in England and Wales, and the fair is well attended by members and the general public. The different events are attended by different angling club representatives and provided an opportunity to promote the questionnaire across a reasonable geographic coverage, whilst minimising bias in responses from particular regions. All of the events were attended in July 2015. Hard copies of the questionnaires were also made available to minimise potential for selection bias by excluding anglers that do not use the Internet. Despite attempts to reduce potential bias through promotion of the questionnaire at other angling events, it should be recognised that data derived from this survey are assumed to represent the maximum percentage of anglers currently conducting biosecurity in GB.

\section{Questionnaire survey design}

This study focused on quantifying the potential for recreational angling to facilitate jump dispersal of NNS from Europe to GB by investigating the frequency at which anglers travelled to different countries and undertook biosecurity after a fishing trip. Given this overall aim, a closed-format 
questionnaire was deemed the most appropriate approach. Questions that required more extensive individual responses such as names of fishing sites had a 'free-text' option included. Interviews and group discussions would have provided a greater insight into why individuals behave in particular ways and how this is influenced by different factors (Longhurst 2010). However, interviews and group discussions would not have reached the high volume of respondents required in this study. Using a web-based approach enabled access to greater numbers of anglers across a larger geographical area within GB (Schmidt 1997).

The questionnaire was organised into marked sections applying filter questions to avoid asking irrelevant questions to the respondents. For example, after asking an individual whether they went fishing abroad, if a respondent answered 'no' the questionnaire would automatically skip to the next relevant section. This ensured that the questionnaire was as easy to follow and fill in as possible, thus maximising the number of respondents that completed the questionnaire.

The questionnaire was phrased to allow comparison against the baseline angling awareness survey undertaken by Anderson et al. (2014) in 2011. The first section focused on frequency and patterns of movement of anglers within GB and abroad. Answers were generally quantitative, employing statements such as fishing once a week, every two weeks rather than more generic 'often', 'sometimes' statements thereby providing a more accurate representation of their activity (Angelsen and Lund 2011). The second section explored the use of different equipment such as nets, slings, waders, and the frequency with which equipment was cleaned and dried. The CCD campaign, as launched in 2011 has been used to promote awareness of INNS and simple biosecurity guidance that can be undertaken by the general public and practitioners in the field to reduce the risk of spreading INNS. It is focused on three main elements: 'Check'—examining equipment, boats and clothing and removing any fragments of plants, mud or other material, 'Clean'thoroughly washing equipment and clothing in hot water or disinfectant, and 'Dry'-leaving equipment and clothing to dry in the sunlight for at least two days. As these are the key messages promoted by the campaign, these were used to phrase questions around biosecurity procedures conducted by anglers. The final section of the questionnaire included questions on angler awareness of the CCD campaign and INNS. It is recognised that, by using the terminology 'INNS', the questionnaire overlooks non-native species, which after a lag phase, have the potential to become invasive at a later stage (Crooks et al. 1999). However, the focus on the study was to ascertain anglers awareness of INNS. Thus, although biosecurity measures undertaken by anglers are likely to minimise introduction of all non-native species being spread by this vector, to ensure clarity in the questionnaire only the term INNS was used. This section was placed at the end of the survey to minimise the risk of conditioning the respondents' answers surrounding their cleaning and drying behaviour in the earlier section of the questionnaire. This survey complied with University College London (UCL) guidelines on ethical conduct. Respondents were asked for their age, gender and the first 3-4 digits of their postcode. This information would not enable any respondent to be identified. All data were collected and stored anonymously.

A pilot study was undertaken to pre-test the survey before publishing it online. This ensured that questions were interpreted correctly and that sufficient answer options were available for the closed questions (Gaddis 1998). Ten anglers were asked to undertake the online survey. Following the pilot, minor modifications were made to the final questionnaire to improve question clarity and to include additional tick box options in certain questions such as additional angling equipment. The final questionnaire is available in "Appendix".

Data analysis

Differences in biosecurity behaviour between different types of freshwater anglers were analysed. Anglers that fished mainly for Common carp (Cyprinus carpus) were treated as a separate group from general coarse anglers who target other freshwater species such as Bream (Abramas spp.), Roach (Rutilus spp.) and Tench (Tinca spp.) Many anglers undertake sea fishing alongside freshwater fishing. However, due to differences in the environmental tolerances of freshwater and marine INNS, particularly in relation to salinity, anglers that only undertook sea fishing were removed from the analysis. This accounted for three respondents only. Subsequently, five different types of anglers were derived: game, competition, lure, coarse- 
other and coarse-carp. Match anglers are those that fish in competitions in contrast with the other groups that fish simply for pleasure. Demographic information obtained for the 2015 GB Environment Agency (EA) rod licence data was used to test the representativeness of the sample compared to the overall GB angling population.

Risk categories were ascertained for each respondent based on the CCD campaign. Four categories of risk were assigned: 'Low', 'Minor', 'Moderate' and 'Major' (Table 1). Anglers categorised as 'Low' risk, cleaned and dried their equipment after every trip. The category 'Low' risk was chosen rather than 'No' risk as there is always a small risk that an INNS could be unintentionally transmitted. Anglers classified as 'minor' risk, cleaned and/or dried their equipment after every 2-5 trips, 'moderate' every 6-10 or $11+$ trips, and 'major' risk did not clean and/or dry their angling equipment at all. For further clarification, respondents were classified according to their most infrequent cleaning or drying activity. For example, an angler that cleaned their equipment every 6-10 trips, and dried their equipment every time was placed in the moderate risk category. A limitation of this approach is that it assumes equal importance of cleaning and drying in minimising the risk of invasive species being spread. However, some studies suggest that cleaning equipment using hot water is more effective than drying for rapid decontamination of equipment, causing $99 \%$ mortality within an hour, compared to drying that took several days (Anderson et al. 2014). For the initial risk analysis, it was also assumed that respondents were cleaning and drying their equipment in accordance with the Check, Clean, Dry campaigns, using hot water at $45{ }^{\circ} \mathrm{C}$ (Anderson et al. 2015) and drying their equipment until it was completely dry. This assumption was reviewed in the analysis.
To assess temporal changes in the biosecurity activity of anglers, only anglers that fished at least once a fortnight were included to reflect the approach used in the 2011 baseline data collection. Consequently, for this part of the analysis only 79\% (anglers that fished once a fortnight) of the 680 responses were used.

The first 3-4 digits of the respondent's postcode were converted into longitude and latitude data using Doogal (http://www.doogal.co.uk/BatchGeocoding. php). These data were then superimposed onto a map of GB in ArcMap (version 10.3.1) to assess the geographic distribution of the sample angler population, and to identify any spatial patterns in the distribution of anglers of different risk in GB.

Kolmogorov-Smirnov tests were undertaken in SPSS 24 to determine the representativeness of the sample questionnaire in relation to the entire British freshwater angling population. Age and gender demographic data were compared against environment agency (EA) rod licence data for 2015 following similar comparisons conducted by Anderson et al. (2014) and White et al. (2005). Rod licence was used as any angler wishing to fish in freshwater bodies in GB requires a licence. Chi squared tests were employed to determine relationships between the risk of types of anglers, their risk categories and awareness of the CCD. As there were less than five anglers who stated that they mainly lure fish, these were removed from this aspect of the analysis to meet the assumption of the Chi squared test. Both tests had over 500 sets of observations indicating robust p-values (Jaeger 2008). Post-hoc Cramer tests were applied to the risk and biosecurity awareness Chi squared tests to assess the significance and size of the effect.

Table 1 Categorisation of anglers' risk based on their cleaning and drying frequency

\begin{tabular}{|c|c|c|}
\hline $\begin{array}{l}\text { Risk } \\
\text { category }\end{array}$ & Cleaning and drying frequency & Example \\
\hline Low & Every trip & Individual cleans and dries after every angling trip \\
\hline Minor & Undertake both every $2-5$ trips & $\begin{array}{l}\text { Angler may clean his/her equipment every trip but only dries } \\
\text { it every } 2-5 \text { trips or vice versa }\end{array}$ \\
\hline Moderate & Every 6-10 trips for both cleaning and drying & $\begin{array}{l}\text { Angler may only clean his/her equipment every } 6-10 \text { trips, } \\
\text { but dries every } 2-5 \text { or vice versa }\end{array}$ \\
\hline Major & $\begin{array}{l}\text { Does not undertake both parts of the biosecurity } \\
\text { process (clean, dry). }\end{array}$ & Angler cleans his/her equipment after a trip but does not dry it \\
\hline
\end{tabular}




\section{Results}

Data representativeness

Six-hundred and eighty questionnaires were collected (Fig. 1). This included 637 from the online survey and
43 from hard-copy questionnaires. Respondents represented all of the different types of angling. Respondents represented all of the different groups of angling. Coarse (excluding carp) and game anglers were the most popular types of anglers accounting for $46 \%$ and $28 \%$ of respondents respectively. $98 \%$ of the

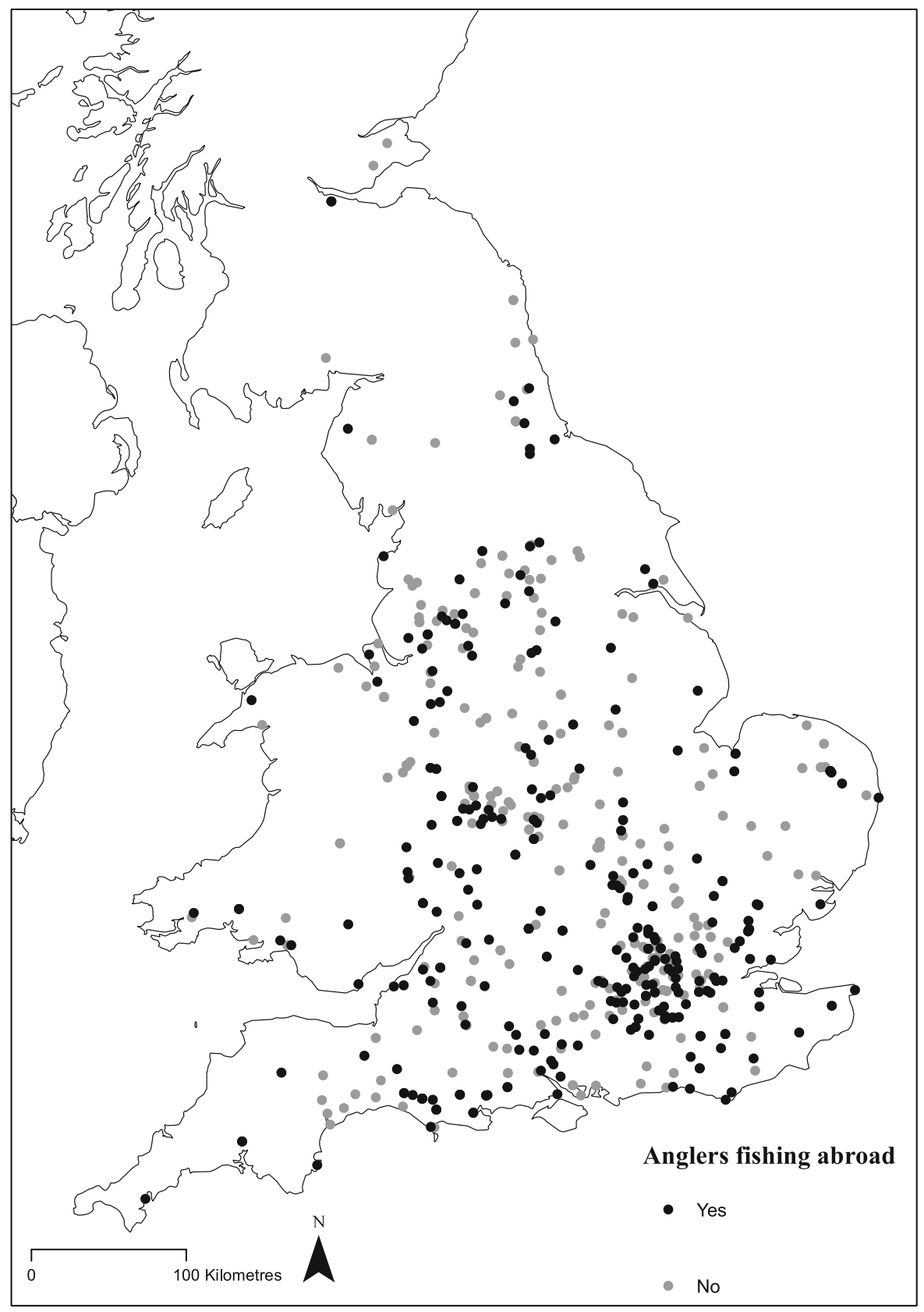

Fig. 1 Spatial distribution of anglers that responded to the questionnaire. Anglers that fish abroad are shown in black whilst anglers that only fish in the UK are shown in grey. Locations were identified using the first 3-4 digits of respondents postcode 
Table 2 Frequency of fishing trips of British anglers within the UK (\%), by fishing type. The group coarse carp refers to anglers that primarily fish for common carp Cyprinus carpio and is treated as a separate group from anglers that fish primarily for other fish species such as roach, tench, bream and rudd (Coarse excluding carp)

\begin{tabular}{|c|c|c|c|c|c|c|c|c|}
\hline & \multicolumn{8}{|c|}{ Frequency of fishing per angler type $(\%)$} \\
\hline & $\begin{array}{l}\text { More than } \\
\text { once a week }\end{array}$ & $\begin{array}{l}\text { Once a } \\
\text { week }\end{array}$ & Fortnightly & $\begin{array}{l}\text { Every } \\
3 \text { weeks }\end{array}$ & $\begin{array}{l}\text { Once a } \\
\text { month }\end{array}$ & $\begin{array}{l}\text { Once every } \\
2 \text { months }\end{array}$ & $\begin{array}{l}\text { Once every } \\
3 \text { months }\end{array}$ & $\begin{array}{l}\text { Less than once } \\
\text { every } 3 \text { months }\end{array}$ \\
\hline All & 32.1 & 29.1 & 17.3 & 7.1 & 7.5 & 2.0 & 1.4 & 3.4 \\
\hline Coarse carp & 29.7 & 35.2 & 17.6 & 3.3 & 8.8 & 2.2 & 1.1 & 2.2 \\
\hline $\begin{array}{l}\text { Coarse (excluding } \\
\text { common carp Cyprinus } \\
\text { carpio) }\end{array}$ & 31.6 & 30.5 & 16.2 & 8.1 & 7.7 & 2.2 & 0.7 & 2.9 \\
\hline Lure & 18.8 & 43.8 & 37.5 & 0.0 & 0.0 & 0.0 & 0.0 & 0.0 \\
\hline Game & 31.7 & 22.6 & 18.3 & 9.1 & 7.3 & 2.4 & 3.0 & 5.5 \\
\hline Competition & 54.5 & 33.3 & 9.1 & 0.0 & 3.0 & 0.0 & 0.0 & 0.0 \\
\hline
\end{tabular}

respondents were male, with the greatest proportion of respondents were aged $65+(34 \%)$ and 55-64 (29\%). No significant difference was detected between the demographic ratios of the two groups (K-S Test, $D=0.13, p>0.05)$. The majority of respondents lived in England (Fig. 1). No respondents came from the Republic of Ireland. Motor vehicles were the primary mode of transport for $95 \%$ of respondents visiting angling waters in Britain.

Seventy-nine percent of all respondents fished at least once a fortnight, and $61 \%$ fished at least once a week (Table 2). Lure and competition anglers fished most frequently, with $100 \%$ and $97 \%$ of anglers fishing once a fortnight respectively. Game anglers fished the least often, with $72.6 \%$ of this group fishing once a fortnight. There was no significant difference between the frequency of fishing trips and type of angler $(n=576, d f=4, p=0.138)$.

Fishing abroad

Three hundred of the respondents (44\%) used their fishing equipment abroad (Fig. 1), visiting over 70 different countries (Table 3) on six continents. Some $82 \%$ of anglers fishing abroad visited at least one European country, with 22 of the current $28 \mathrm{EU}$ Member States listed as a fishing destination. 177 (59\%) of British anglers fishing abroad only visited water bodies and fisheries in Europe. Countries in Western Europe were the most popular angler destination, with France and Ireland the most frequently visited countries accounting for $33.3 \%$ and $27 \%$ of trips abroad respectively (Fig. 2). The USA and Canada were the most frequently visited countries outside of Europe (17.3\% and $10.7 \%$ abroad trips, respectively). A total of $49(16.3 \%)$ anglers fishing abroad exclusively visited sites outside of Europe.

Cars and vans were the primary mode of transport for some $43 \%$ of the anglers fishing abroad. Airplane travel represented the second most popular mode of transport for anglers fishing abroad, accounting for $34.7 \%$ of travel. For British anglers that fished exclusively in Western Europe (Scandinavia, the Netherlands, France, Spain, Ireland, Iceland and Portugal) some $64.7 \%$ used motor vehicles as their primary mode of transport. $18.4 \%$ and $16.2 \%$ of anglers also used airplanes and ferries to travel to these Western European countries. 69.4\% of anglers fishing exclusively in France and The Netherlands travelled primarily by car or van.

\section{Angler risk}

Some $46 \%$ and $45 \%$ of anglers that fished at least once a week or fortnightly, respectively, were categorised as low risk, cleaning and drying their equipment after every trip (Table 4). Minor and moderate risk accounted for $23.5 \%$ and $9.7 \%$ of anglers, respectively. In total, $80 \%$ of anglers were conducting some form of biosecurity occasionally after a fishing trip. Major risk anglers that were not cleaning and/or drying their equipment after every trip accounted for $19.5 \%$ of anglers. Some $50.4 \%$ of anglers fishing less than once per fortnight were considered low risk. 
Table 3 Frequency of travel of British anglers to different countries for fishing as proportion of the total number $(n=680)$ of respondents and a percentage of anglers fishing abroad (total anglers travelling abroad $\mathrm{n}=300)(\%)$. Islands placed within brackets were grouped together to represent a single country

\begin{tabular}{|c|c|c|c|}
\hline Country & $\begin{array}{l}\text { Total number of } \\
\text { respondents }\end{array}$ & $\begin{array}{l}\text { Percentage of total } \\
\text { anglers }\end{array}$ & $\begin{array}{l}\text { Percentage of anglers } \\
\text { traveling abroad }\end{array}$ \\
\hline \multicolumn{4}{|l|}{ Europe } \\
\hline France & 100 & 14.7 & 33.3 \\
\hline Ireland & 81 & 11.9 & 27.0 \\
\hline Spain & 44 & 6.5 & 14.7 \\
\hline Netherlands, Norway & 24 & 3.5 & 8.0 \\
\hline Germany & 14 & 2.1 & 4.7 \\
\hline Iceland & 12 & 1.8 & 4.0 \\
\hline Italy & 11 & 1.6 & 3.7 \\
\hline Denmark & 10 & 1.5 & 3.3 \\
\hline Cyprus, Greece, Portugal, Sweden & 8 & 1.2 & 2.7 \\
\hline Belgium, Turkey & 5 & 0.7 & 1.7 \\
\hline Slovenia & 4 & 0.6 & 1.3 \\
\hline Poland, Romania & 3 & 0.4 & 1.0 \\
\hline $\begin{array}{l}\text { Czech Republic, Hungary, Malta, Bosnia and } \\
\text { Herzegovina }\end{array}$ & 2 & 0.3 & 0.7 \\
\hline Finland, Luxembourg, Slovakia, Switzerland & 1 & 0.2 & 0.3 \\
\hline \multicolumn{4}{|l|}{ North and South America } \\
\hline USA & 52 & 7.6 & 17.3 \\
\hline Canada & 32 & 4.7 & 10.7 \\
\hline Cuba & 12 & 1.8 & 4.0 \\
\hline $\begin{array}{l}\text { (Canary Islands, Tenerife, Lanzarote, Grand Union), } \\
\text { (Trinidad and Tobago) }\end{array}$ & 7 & 1.0 & 2.3 \\
\hline Argentina, Cyprus, Thailand & 6 & 0.9 & 2.0 \\
\hline $\begin{array}{l}\text { Antigua, (West Indies, Caribbean, British Virgin Islands, } \\
\text { Barbados) }\end{array}$ & 5 & 0.7 & 1.7 \\
\hline Alaska, Brazil & 4 & 0.6 & 1.3 \\
\hline Mexico & 3 & 0.4 & 1.0 \\
\hline Cayman, Chile, & 2 & 0.3 & 0.7 \\
\hline Guyana, Peru, Suriname, Venezuela, Jamaica & 1 & 0.2 & 0.3 \\
\hline \multicolumn{4}{|l|}{ Russia } \\
\hline Russia & 8 & 1.2 & 2.7 \\
\hline Kazakhstan & 1 & 0.2 & 0.3 \\
\hline \multicolumn{4}{|l|}{ Africa } \\
\hline South Africa & 7 & 1.0 & 2.3 \\
\hline Seychelles & 4 & 0.6 & 1.3 \\
\hline Belize, Kenya & 3 & 0.4 & 1.0 \\
\hline Egypt, Gambia, Mauritius, & 2 & 0.3 & 0.7 \\
\hline $\begin{array}{l}\text { Guyana, Morocco, Myanmar, Nepal, Oman, Peru, } \\
\text { Uganda, Zambia }\end{array}$ & 1 & 0.2 & 0.3 \\
\hline \multicolumn{4}{|l|}{ Asia } \\
\hline $\begin{array}{l}\text { India, Myanmar, Nepal, Oman, Outer Mongolia, } \\
\text { Philippines, Singapore, }\end{array}$ & 1 & 0.2 & 0.3 \\
\hline \multicolumn{4}{|l|}{ Australasia } \\
\hline New Zealand & 14 & 2.1 & 4.7 \\
\hline Australia & 9 & 1.3 & 3.0 \\
\hline Tasmania & 1 & 0.2 & 0.3 \\
\hline
\end{tabular}




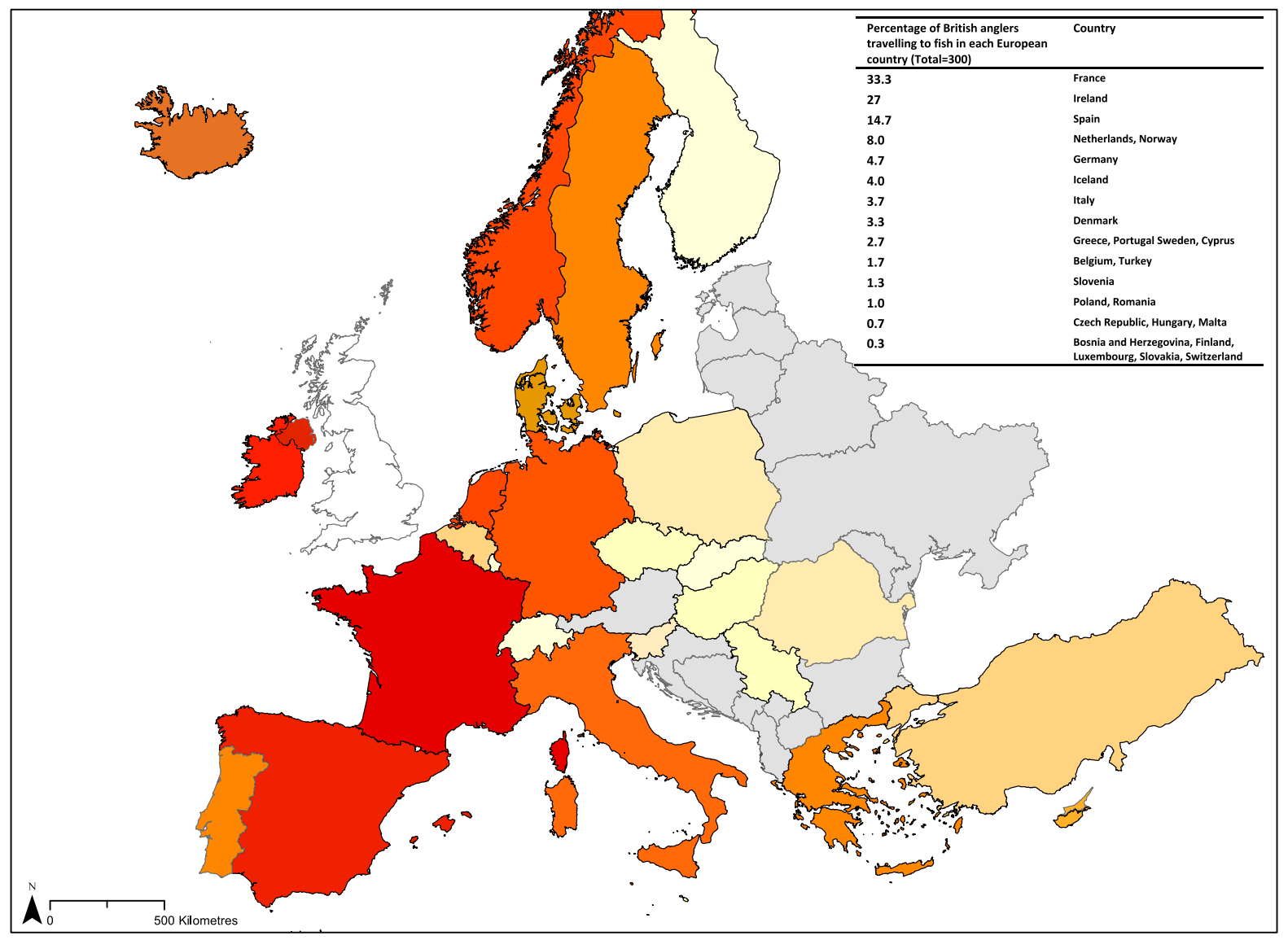

Fig. 2 Movement of British anglers to different fishing destinations in Europe. Values are given as a percentage of the number of British anglers travelling abroad. Colours were assigned from a gradient of yellow (low), orange (medium) and red (high) to represent the percentage of British anglers visiting each European country. Countries which were not visited by any British anglers are shown in grey. The individual numbers are available in Table 3

Table 4 Risk categorisation of anglers fishing at least once a week or once a fortnight (\%)

\begin{tabular}{lllc}
\hline & Anglers fishing once a week & Anglers fishing once a fortnight & Anglers fishing less than once a fortnight \\
\hline Low & 46.1 & 44.8 & 50.4 \\
Minor & 23.6 & 23.7 & 21.0 \\
Moderate & 11.8 & 12.0 & 7.6 \\
Major & 18.5 & 19.5 & 21.0 \\
\hline
\end{tabular}

There was no spatial pattern in the distribution of anglers of different biosecurity risk within GB (Fig. 3).

The biosecurity risk of anglers fishing at least once a fortnight was investigated and a similar percentage for the angler risk was identified. Over $40 \%$ of anglers fishing at least once a fortnight were low risk (Table 4). Twenty percent of anglers that fished at least once a fortnight were classified as major risk. $17 \%$ of anglers fishing once a fortnight never cleaned or dried their equipment after fishing.

Except for competition anglers, $40 \%$ of anglers represented by each angler type were categorised as low risk. The carp and game angler categories had the greatest proportion of low risk anglers at 55\% and $52.2 \%$, respectively. Carp anglers had the lowest 


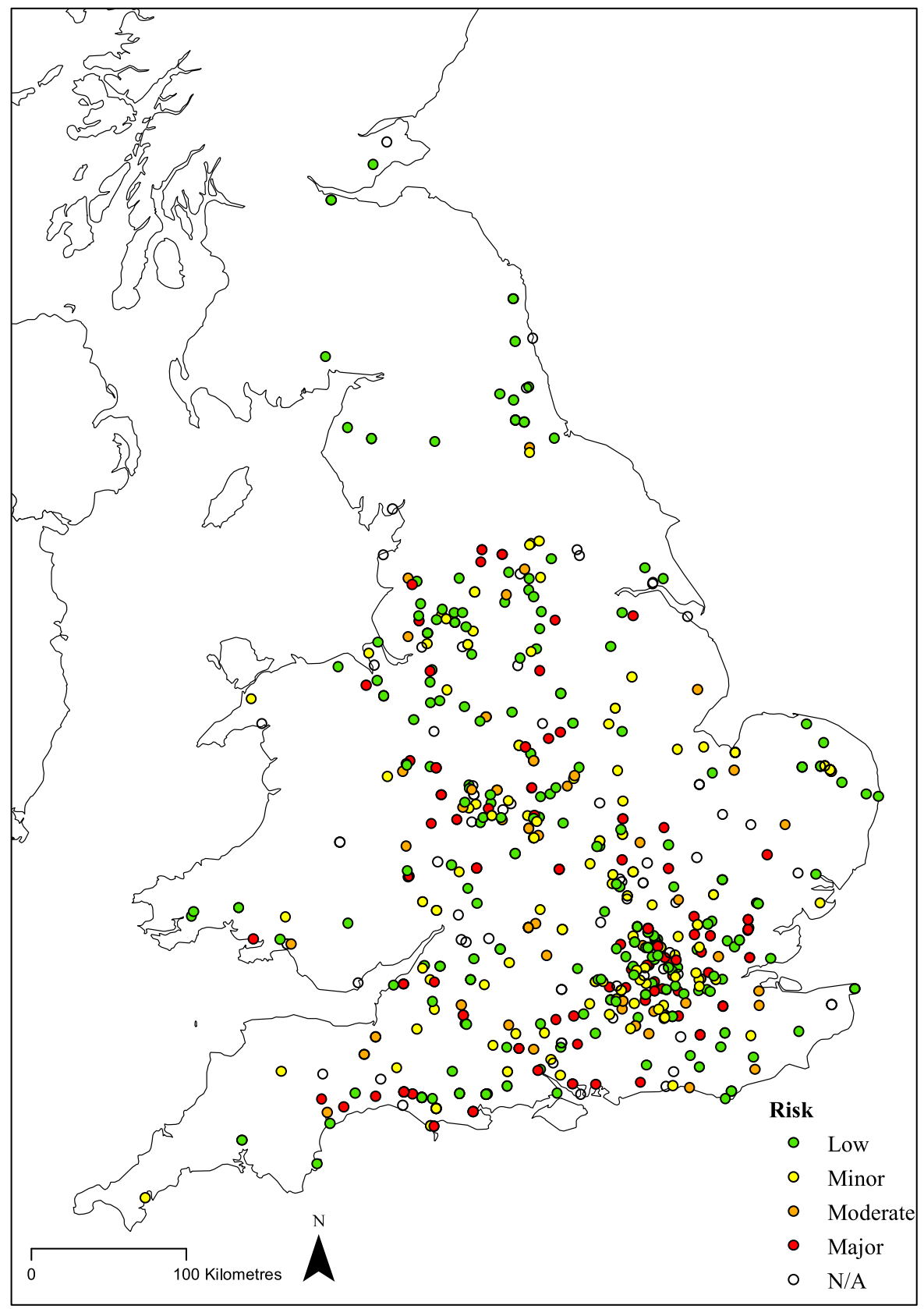

Fig. 3 Geographic distribution of anglers of different risk throughout Britain. Locations were identified using the first 3-4 digits of their postcode

percentage of high risk anglers, with $12.5 \%$ compared to over $20 \%$ for coarse, game and competition (match) anglers. However, these differences were not significant ( $\mathrm{n}=525, d f=3 p=0.105)$.

Some $46 \%$ of anglers had heard of the CCD campaign. Anglers that had heard of CCD were more likely to undertake biosecurity after every trip (Fig. 4).
One-quarter of anglers that had heard of the campaign cleaned and dried their equipment after every trip. $17.6 \%$ of anglers that had not heard of the campaign were classified as a moderate or major biosecurity risk. $12.3 \%$ of anglers that had heard of the campaign fell into these two categories. Differences in the risk of anglers based on their awareness of the CCD 


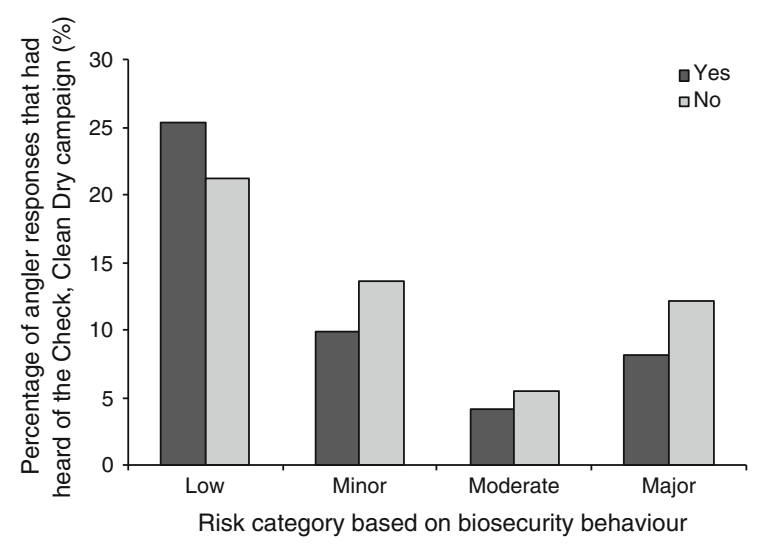

Fig. 4 Awareness of British anglers of the Check, Clean Dry biosecurity campaign and their risk category according to the frequency they clean and dry their equipment

campaign were significant $\left(X^{2}=9.017, \mathrm{n}=528\right.$, $d f=3, p=0.03)$. A post hoc Cramer's test of a significant Chi squared test revealed a weak (0.131), significant relationship between the awareness of anglers of the CCD campaign and their risk category $(p=0.03)$.

Of the anglers that undertook biosecurity, 33\% cleaned their equipment using hot water. Over $40 \%$ used cold water, and $10.8 \%$ washed their equipment at a water bank (Fig. 5). For 37\% of anglers cold water was the sole method used to clean their equipment, without any application of detergent or disinfectant. The use of cold water as the only cleaning approach also accounted for $31 \%$ of anglers in the low risk category. Some $16.2 \%$ of anglers did not conduct any cleaning.

\section{Temporal changes in angler biosecurity behaviour}

The proportion of anglers cleaning and drying their equipment after every trip rose from $21 \%$ in 2011 to $35.5 \%$ in 2015 (Fig. 6). Cleaning frequency also rose over this period from 22 to $37.8 \%$. In contrast, drying frequency fell from 80 to $52.8 \%$. Coinciding with an increase in low risk anglers, the percentage of highrisk anglers not undertaking any biosecurity rose from $11.9 \%$ in 2011 to $19.5 \%$ in 2015 . Restricting analysis to anglers fishing fortnightly and going abroad on fishing trips, the proportion of high-risk anglers increased from $18 \%$ to almost $31.8 \%$.

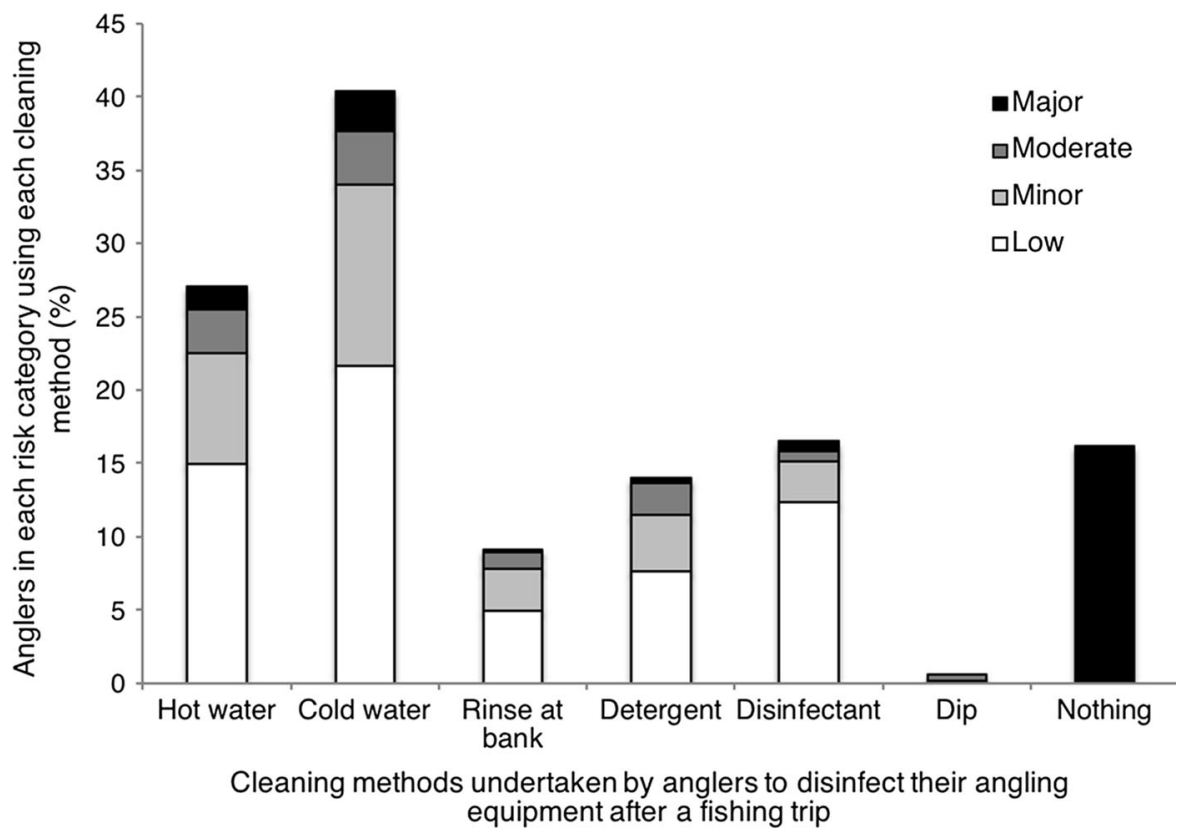

Fig. 5 Methods used by British anglers to clean their equipment after a fishing trip. Some anglers used multiple methods, as a result, the sum of percentages is greater than $100 \%$. 'Dip' refers to disinfection through equipment by submersion in a container containing disinfectant provided by the fishery 


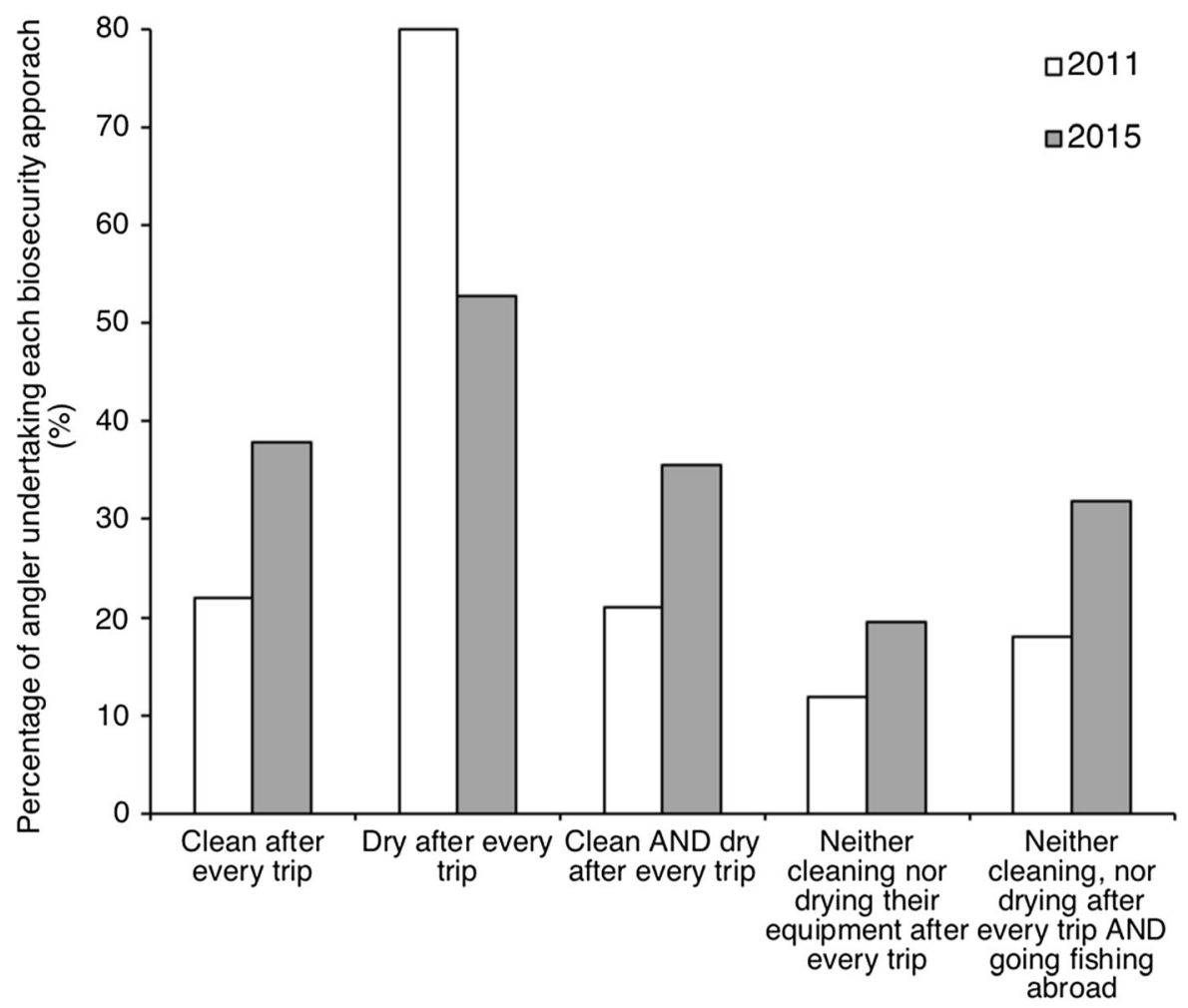

Temporal differences in biosecurity behaviour of anglers in 2011 and 2015

Fig. 6 Temporal change in the biosecurity of anglers fishing at least once per fortnight since the launch of the Check, Clean Dry campaign in March 2011. Baseline 2011 data was sourced from Anderson et al. (2014)

Table 5 Estimated duration in hours of ferry journeys between the UK and the Netherlands, Belgium France and Ireland. (Source: Brittany Ferries and P\&O Ferries http://www.poferries.com/en/portal Accessed 02/06/2016)

\begin{tabular}{llll}
\hline Ferry routes between Europe, Ireland and & $\begin{array}{l}\text { Estimated duration } \\
\text { (h) }\end{array}$ & $\begin{array}{l}\text { Frequency of ferries (number per } \\
\text { day) }\end{array}$ & $\begin{array}{l}\text { Number of cars per } \\
\text { ferry }\end{array}$ \\
\hline Dover-Calais & 1.50 & 23 & $520-1059$ \\
Hull-Rotterdam & 12.00 & 1 & $250-850$ \\
Hull to Zeebrugge & 13.25 & 1 & $250-850$ \\
Poole to Cherbourg & 4.50 & 1 & 590 \\
Portsmouth to Caen & 6.00 & 4 & $600-800$ \\
Portsmouth to Cherbourg & 3.00 & 2 & 235 \\
Portsmouth to Le Havre & 3.45 & 1 & $160-200$ \\
Portsmouth to St Malo & 8.00 & $1-2$ & 580 \\
Plymouth to Roscoff & 5.00 & 5 & 470 \\
Cairnyan to Belfast & 2.25 & 6 & 660 \\
Cairnryan to Larne & 2.00 & 7 & $316-375$ \\
Fishguard to Rosslare & 3.25 & 2 & 564 \\
Liverpool to Belfast & 8.00 & 2 & 85 \\
Liverpool to Dublin & 7.50 & 3 & $80-125$
\end{tabular}




\section{Discussion}

Angling as a pathway for the unintentional introduction of INNS from Europe

Responding to the obligation for GB to investigate potential human pathways and vectors of INNS introduction, this study represents the first known study assessing the potential for anglers to act as unintentional vectors for the spread of invasive species between countries in Europe. Over $40 \%$ of anglers used their equipment abroad for fishing. With 4 million estimated anglers in GB (EA 2004) this extrapolates to around 1.76 million GB anglers potentially travelling abroad with their angling equipment, often to two countries or more. This includes potentially 588,000 travelling to France for fishing, and 847,100 travelling to a country in Western Europe including The Netherlands and Norway. Horizon scanning studies indicate there are at least 16 freshwater invasive species present within Western Europe that are of medium or high-risk of entering GB (Roy et al. 2014; Gallardo et al. 2016), including at least 10 aquatic Ponto-Caspian INNS (Gallardo and Aldridge 2013a). In addition to invasive species, invasive parasites and pathogens such as the ecto-parasite Salmon louse (Gyrodactylus salaris) also represent a major biosecurity concern to British waters. Gyrodactylus salaris has had devastating impacts on salmon populations in invaded Norwegian rivers and if introduced to GB is likely to have similar negative impacts on GB salmon populations (Peeler et al. 2004). Given the bioclimatic similarities between Western Europe and GB (Gallardo and Aldridge 2013b), it is anticipated that any INNS establishing in these regimes have a high likelihood of being able to survive and spread within GB (Gallardo and Aldridge 2013b, 2015). Consequently, Western Europe represents a substantial source for new invasive species that could be introduced by recreational pathways such as angling.

In addition to the establishment of new INNS there is also the risk of introducing new genetic and phenotypic strands of INNS already established in GB. Some INNS are limited in their current distribution due to genetic or fitness bottlenecks, meaning they are not adequately suited to the environment they have invaded (Crooks et al. 1999). The introduction of new phenotypic variants from different source regions could release the INNS from these environmental restrictions and facilitate expansions in their distribution, thereby increasing impacts on invaded habitats (Lavergne and Molofsky 2007; Forsman 2014). In GB, some invasive species with limited distribution such as Floating water primrose (Ludwigia grandiflora) have been targeted for eradication. The introduction of new phenotypic strands or populations could therefore undermine efforts to control or eradicate these INNS.

With over $40 \%$ of British anglers primarily travelling to European fishing sites by motor vehicle, there is a substantial risk of invasive species being transported back into GB on damp angling equipment. Current estimates of the desiccation tolerance of INNS indicate that some are capable of surviving for up to 15 days on damp angling equipment, with this including invasive species already established in GB such as Killer shrimp (Dikerogammarus villosus) and Zebra mussel (Dreissena polymorpha) (Fielding 2011; Anderson et al. 2014). The ability of INNS species to survive the return journey on damp equipment in motor vehicles needs to be further tested but results from current desiccation studies on INNS, coupled with the short travel time (2-14 h to return from Western Europe to GB) (Table 5) suggests potential for a number of high-risk INNS to be unintentionally transported back from Europe to GB via this conduit. Except for a few studies on individual lakes (BacelaSpychalska et al. 2013), the presence of INNS in European fishing lakes is little known. The determination of new INNS of high risk of being introduced in GB could potentially provide an alternative or complimentary approach to horizon scanning.

Awareness and implementation of biosecurity

It should be recognised that self-report style questionnaires are vulnerable to social desirability response bias, with participants potentially stating answers that they believe to be socially acceptable, or desirable by the researcher (Randall and Fernandes 1991; Lajunen and Summala 2003). This cannot be factored out of any questionnaire (Brace 2008). As a result, it is possible that some respondents may overestimate how often they clean and dry their equipment in order to satisfy the surveyor (Cliff and Campbell 2012). Therefore, although the demographic analysis indicated this study was representative of British angler population holding a rod licence in 2015 , the findings 
of this questionnaire should be interpreted with caution. Furthermore, the opt-in nature of this questionnaire means there is potential for a greater response from individuals that are aware and care about conservation issues, or who represent more affluent members of the angling community due to the recruitment of responses via the Internet and at the game fair event (White et al. 2005). These individuals are therefore more likely to have excess income to spend on fishing trips abroad. The percentages presented here should therefore be seen as representing a maximum estimate for anglers fishing abroad and undertaking biosecurity. Taking these factors into account, despite the potential respondent errors, the marked increase in biosecurity implementation since 2011 can undoubtedly be attributed to greater uptake of biosecurity. Therefore, there is evidence that anglers are becoming more aware of the risk of invasive species, resulting in the implementation of measures aimed at reducing the risk of dispersing species between water bodies.

Despite the substantial increase in the number of anglers undertaking biosecurity in our study, only $48 \%$ of anglers claimed to be aware of the Check Clean Dry campaign. This compares to New Zealand where $80 \%$ of recreational users are aware of an equivalent initiative (Anderson 2015). Initiated in 2004, the New Zealand campaign represents a long-established initiative, promoted through a national campaign, and implemented through regional biosecurity plans. Greater levels of awareness may therefore be partially due to the longer exposure of water users to the campaign. However, differing levels in awareness of the campaign, may also be partially attributed to the communication channels through which individuals are hearing about the campaign. Whilst $54 \%$ of water users in the regional area of Bay of Plenty, New Zealand had heard of the campaign through signage at boat ramps (Anderson 2015), the majority of British anglers were made aware of the CCD through angling magazines or environmental organisations. Consequently, although British anglers were being informed of the importance of biosecurity, this may not be explicitly tied to the Check, Clean Dry campaign, with this reflected by a weak, but significant association recorded between anglers' awareness of the campaign and their likelihood of frequently undertaking biosecurity. Therefore, it is suggested that practitioners should exercise caution in using awareness of the
Check Clean Dry campaign as the sole predictor of biosecurity uptake by the public in GB. Instead, a combination of factors, including measures of action after leaving the water should be used to monitor uptake of biosecurity procedures.

There has been a marked increase in the total proportion of anglers undertaking some form of biosecurity, in terms of either cleaning or drying their equipment occasionally after a fishing trip. However, over the same time period there has also been a $7 \%$ increase in the number of anglers who are not undertaking any biosecurity. INNS are highly adaptable species, capable of regenerating and spreading from a single plant node, asexual invertebrate or eggbearing macroinvertebrate (Havel and Shurin 2004; Hussner 2009; Okada et al. 2009; Pigneur et al. 2011; Bruckerhoff et al. 2015; Riccardi 2015). Consequently, the unintentional introduction of a single viable plant fragment or live INNS specimen is all that is required to enable a new INNS population to establish. Further work is therefore required to engage with anglers that are still not conducting adequate biosecurity measures. This includes identifying the factors that are currently preventing anglers from undertaking biosecurity. Anglers stated that the availability of a cleaning station and the visual cleanliness of the equipment were some of the main reasons affecting whether an angler cleaned their equipment after use, with the financial cost of undertaking biosecurity and the availability of information being less important. These factors have also been reported as some of the main reasons inhibiting biosecurity for canoeists and boaters (Anderson et al. 2014; De Ventura et al. 2017). Going forward, the importance of routinely cleaning equipment needs to be reiterated, and more resources need to be assigned to ensure easy access to cleaning facilities at the angling waters. In addition to promotion of the CCD campaign, greater clarification is still required on the appropriate methods for cleaning equipment. The use of hot water is increasingly considered to be one of the most efficient, environmentally friendly and cost-effective methods for cleaning equipment and clothing (Beyer et al. 2010; Perepelizin and Boltovskoy 2011; Stebbing et al. 2011; Anderson et al. 2015; Sebire et al. 2018). Disinfectants such as Virkon ${ }^{\circledR}$ Aquatic and Virasure ${ }^{\circledR}$ have also been proposed as effective approaches to decontaminate equipment and small watercraft (Coughlan et al. 2018; Cuthbert et al. 2018). However, 
although the percentage of anglers cleaning their equipment has risen since the launch of the $\mathrm{CCD}$ guidance, $50 \%$ of anglers are using cold water. For 'low' risk anglers cleaning their equipment after every trip, cold water cleaning accounted for the only cleaning method for $31 \%$ of the category. These findings indicate that although anglers are undertaking cleaning approaches, their 'cleaning' method may not be effective in killing any attached INNS. It is therefore essential that promoters of the CCD campaign provide clearer messaging regarding effective cleaning.

\section{Conclusions}

Following the launch of the EU Regulation (1143/2014) in 2015, EU Member States are obliged to investigate potential anthropogenic pathways of INNS introduction and create pathway action plans (PAPs) for INNS pathways identified as being a risk (Caffrey et al. 2014; Beninde et al. 2014). This study represents the first attempt at quantifying the importance of angling as an international pathway, providing estimates of the volume of British anglers travelling to Europe for recreational fishing as well as valuable insights into changes in anglers' behaviour since the launch of the invasive species-specific CCD campaign. Although this study has focused on angling within $\mathrm{GB}$, it needs to be recognised that the angling pathway is potentially a global one. With limited biogeographic boundaries between many countries in continental Europe (Rahel and Olden 2008), the potential two-way cross-border movement of INNS by anglers could be significant for many countries. As a result, British anglers travelling abroad could also unintentionally introduce new populations of INNS into water bodies in the destination country. The findings of this study are therefore highly relevant to any country that receives a high volume of British anglers including Ireland and France. This is clearly exemplified by the recent outbreak of Crayfish plague (Aphanomyces astaci) in the Republic of Ireland. Considered a last refuge for many native European freshwater species, Ireland is an Ark site for White clawed crayfish (Austropotamobius pallipes). Until recently there were no reported occurrences of the invasive Signal crayfish ( $P$. leniusculus) or the crayfish plague that $P$. leniusculus carries. However, in 2017, the presence of the plague was confirmed in the River Suir,
County Tipperary, Republic of Ireland, and at time of writing had spread into four different catchments. No signal crayfish have been found so the source of the plague is unknown. There have been some suggestions that it may have been introduced on damp equipment (kayaks, nets, pleasure boats, waders). However, as there are many different users of these catchments, the original source of the introduction cannot be verified. Further research into the ability of pathogens to survive on equipment, and investigations into the presence of invasive species in private fisheries, sailing clubs or other water bodies will help to disentangle the potential sources of different groups of species or pathogens by each pathway.

Since the launch of the CCD campaign in 2011, the percentage of anglers undertaking biosecurity after every trip has almost doubled. Although changes to other recreational water users are unknown, this suggests that the campaign has been successful in increasing awareness of invasive species and encouraging the public to undertake biosecurity measures. The observed success of the CCD campaign as reported in this study, can be used to inform the angling PAP promoting the use of biosecurity as an invasive management tool. These plans are pathwayspecific and outline the main policy and management approaches available for the various stakeholders involved. In addition to this, the findings of this study are also applicable to other freshwater pathways where biosecurity is being used as a management technique. This includes the use of recreational boat and kayak activity. Exchanges of best practice between different countries and recreational users could therefore be highly effective in reducing the risk of spread of invasive species.

Further work is required to determine what, if any, invasive species are present in European fishing lakes, and to assess the ability of INNS to survive car trips from Europe back to GB. The findings of this work indicate that angling could be an important pathway for the movement of aquatic INNS, particularly from Western Europe into GB.

Acknowledgements The research was supported by a studentship from the UK Natural Environment Research Council (Grant No. NE/L002485/1) as part of the London NERC Doctoral Training Partnership, and a CASE partnership with the Angling Trust. The author would like to thank the Angling Trust for their advice and support in the development of the survey. 
Open Access This article is licensed under a Creative Commons Attribution 4.0 International License, which permits use, sharing, adaptation, distribution and reproduction in any medium or format, as long as you give appropriate credit to the original author(s) and the source, provide a link to the Creative Commons licence, and indicate if changes were made. The images or other third party material in this article are included in the article's Creative Commons licence, unless indicated otherwise in a credit line to the material. If material is not included in the article's Creative Commons licence and your

intended use is not permitted by statutory regulation or exceeds the permitted use, you will need to obtain permission directly from the copyright holder. To view a copy of this licence, visit http://creativecommons.org/licenses/by/4.0/.

\section{Appendix}

\section{Invasive Non-native Species Survey}

\section{Demographic information}

1. Age

\begin{tabular}{|l|l|l|l|}
\hline Under 18 & & $45-54$ & \\
\hline $18-24$ & & $45-54$ & \\
\hline $25-34$ & & $65+$ & \\
$34-44$ & & & \\
\hline
\end{tabular}

2. Sex

\begin{tabular}{|l|l|}
\hline Male & \\
\hline Female & \\
\hline
\end{tabular}

3. Please enter the first three or four digits of your postcode (This will enable us to estimate how far different water users travel to take part in their activities. Using the first 3-4 digits will not reveal your home location to us, only the general area that you live in.)

Postcode:

4. Which type of angling do you do? (Choose all that are appropriate)

\begin{tabular}{|l|l|}
\hline Game & \\
\hline Coarse - carp & \\
\hline Coarse - lure & \\
\hline Coarse - other & \\
\hline Competition & \\
Sea & \\
\hline
\end{tabular}

5. Which type of angling do you do the most often? (Please only choose one from the selection)

\begin{tabular}{|l|l|}
\hline Game & \\
\hline Coarse - carp & \\
\hline Coarse - lure & \\
\hline Coarse - other & \\
\hline Competition & \\
\hline Sea & \\
\hline
\end{tabular}




\section{Threats to UK waterbodies}

6. What do you think are the biggest threats to species in UK rivers and lakes? Please rate the following from 1 to 5 ( 1 = smallest threat $5=$ greatest threat. Only use each number once).

\begin{tabular}{|l|l|l|l|l|l|}
\hline & 1 & 2 & 3 & 4 & 5 \\
\hline Predation & & & & & \\
\hline Pollution & & & & & \\
\hline Invasive non-native species & & & & & \\
\hline Climate change & & & & & \\
\hline Decrease in the quality of habitat & & & & & \\
\hline
\end{tabular}

\section{Movement patterns}

7. How frequently do you do angling?

\begin{tabular}{|c|c|}
\hline More than once a week & Once every month \\
\hline Once a week & Once every 2 months \\
\hline Once every 2 weeks & Once every 3 months \\
\hline Once every 3 weeks & Less than once every 3 months \\
\hline
\end{tabular}

8. On average, how long do you spend at the site when you fish?

\begin{tabular}{|l|l|l|l|}
\hline Under 2 hours & & $8-10$ hours & \\
\hline $2-4$ hours & & $10-12$ hours & \\
\hline $4-6$ hours & & Over 12 hours & \\
\hline $6-8$ hours & & & \\
\hline
\end{tabular}

9. Please list the 3 UK angling venues where you last went fishing in the UK

\begin{tabular}{|l|l|}
\hline Venue name (including nearest town, county) & \\
Venue name (including nearest town, county) & \\
\hline Venue name (including nearest town, county) & \\
\hline
\end{tabular}

10. Please list the 3 UK angling venues that you go to the most frequently

\begin{tabular}{|l|l|}
\hline Venue name (including nearest town, county) & \\
\hline Venue name (including nearest town, county) & \\
\hline Venue name (including nearest town, county) & \\
\hline
\end{tabular}

11. How do you travel to these UK venues? (Choose one or more as relevant)

\begin{tabular}{|l|l|l|l|}
\hline Motor vehicle e.g. car/van & Train & \\
\hline Motorbike & Bus & \\
\hline Cycle & Tube & \\
\hline Walk & Other (please state) & \\
\hline
\end{tabular}


12. What form of transport do you use the most often to travel to the UK angling venues?

\begin{tabular}{|l|l|l|l|}
\hline Motor vehicle e.g. car/van & Train & \\
\hline Motorbike & Bus & \\
\hline Cycle & Tube & \\
\hline Walk & & Other (please state) & \\
\hline
\end{tabular}

\section{Fishing in Europe}

13. Have you ever used your own angling equipment outside of the UK?

\begin{tabular}{|l|l|}
\hline Yes & \\
\hline No & \\
\hline
\end{tabular}

If no, please skip to question 19.

14. If yes, which countries to you go to for fishing?

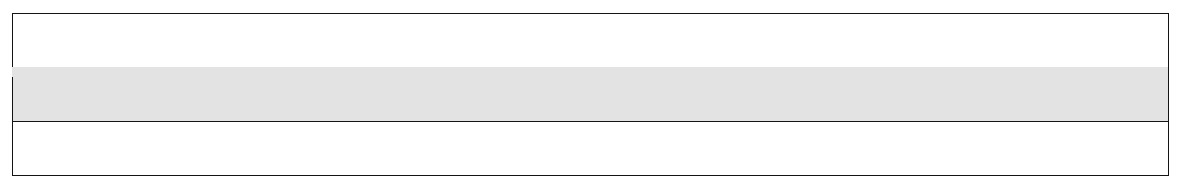

15. Can you list the 3 angling venues that you most recently went fishing in Europe (outside of the UK)

\begin{tabular}{|l|l|}
\hline Venue name (including nearest town, county) & \\
\hline Venue name (including nearest town, county) & \\
\hline Venue name (including nearest town, county) & \\
\hline
\end{tabular}

16. Can you list 3 angling venues you most frequently visit in Europe (outside of the UK)

\begin{tabular}{|l|l|}
\hline Venue name (including nearest town, country) & \\
\hline Venue name (including nearest town, country) & \\
\hline Venue name (including nearest town, country) & \\
\hline
\end{tabular}

17. If yes, how do you travel to these countries?

\begin{tabular}{|l|l|l|}
\hline Motor vehicle e.g. car/van & Ferry & \\
\hline Motorbike & Bus & \\
\hline Airplane & With a fishing company & \\
\hline Eurostar & Other (please state) & \\
\hline
\end{tabular}


18. Which mode of transport do you use the most often to get to the European venues? Please only select one

\begin{tabular}{|l|l|l|}
\hline Motor vehicle e.g. car/van & Ferry & \\
\hline Motorbike & Bus & \\
\hline Airplane & With a fishing company & \\
\hline Eurostar & Other (please state) & \\
\hline
\end{tabular}

\section{Equipment use}

19. Which of the following items of equipment do you use? (Select all that are appropriate)

\begin{tabular}{|l|l|l|l}
\hline Neoprene waders/ wellies & Bass bags & \\
\hline Felt waders/ wellies & Bait boat & \\
\hline Pike tube & Weigh sling & \\
\hline Landing net & Fly fishing belly boats & \\
\hline Keep net & Row boat & \\
\hline Carp/pike/ catfish cradle & Other (please state) & \\
\hline Carp sack & & & \\
\hline
\end{tabular}

20. Where do you store your equipment between trips?

\begin{tabular}{|l|l|}
\hline Indoors & \\
\hline Shed or garage & \\
\hline Outdoors & \\
\hline Other (please state) & \\
\hline
\end{tabular}

21. If you use waders, how many hours do you typically keep them in the water for?

\begin{tabular}{|l|l|l|}
\hline Less than one hour & $7-8$ hours & \\
\hline $1-2$ hours & $8-9$ hours & \\
\hline $2-3$ hours & $9-10$ hours & \\
$3-4$ hours & $10-11$ hours & \\
\hline $4-5$ hours & $11-12$ hours & \\
\hline $5-6$ hours & Over 12 hours & \\
\hline $6-7$ hours & Do not use waders & \\
\hline
\end{tabular}


22. If you use a keep net, how many hours do you typically keep it in the water for?

\begin{tabular}{|l|l|l|}
\hline Less than one hour & $7-8$ hours & \\
\hline $1-2$ hours & $8-9$ hours & \\
\hline $2-3$ hours & $9-10$ hours & \\
\hline $3-4$ hours & $10-11$ hours & \\
\hline $4-5$ hours & $11-12$ hours & \\
\hline $5-6$ hours & Over 12 hours & \\
\hline $6-7$ hours & Do not use a keep net & \\
\hline
\end{tabular}

23. Do you ever enter the water whilst you fish?

\begin{tabular}{|l|l|}
\hline Yes & \\
\hline No & \\
\hline
\end{tabular}

24. Do you ever clean your equipment between trips?

\begin{tabular}{|l|l|}
\hline Yes & \\
\hline No & \\
\hline
\end{tabular}

If no, then please move to question 28

25. If yes, then how frequently?

\begin{tabular}{|l|l|}
\hline After every trip & \\
\hline After $2-5$ trips & \\
\hline After $6-10$ trips & \\
\hline After $11+$ trips & \\
\hline
\end{tabular}

26. What do you use to clean your equipment?

\begin{tabular}{|l|l|}
\hline Hot water & \\
\hline Cold water & \\
\hline Detergent & \\
\hline Disinfectant & \\
\hline Other (please state) & \\
\hline
\end{tabular}


27. How important are the following factors when deciding whether to clean your equipment after a trip?

Please rate the following from 1 to $591=$ not at all important, 5 extremely important. Only use each number once)

\begin{tabular}{|l|l|l|l|l|l|}
\hline & 1 & 2 & 3 & 4 & 5 \\
\hline The availability of a hose/ cleaning station & & & & & \\
\hline The cost of cleaning your equipment & & & & & \\
\hline The time it takes to clean your equipment & & & & & \\
\hline $\begin{array}{l}\text { The availability of information about what to do } \\
\text { How clean your equipment looks at the end of } \\
\text { your trip }\end{array}$ & & & & & \\
\hline
\end{tabular}

28. Do you ever dry your equipment for over 24 hours between each trip? e.g. hang on washing line or in airing cupboard?

\begin{tabular}{|l|l|}
\hline Yes & \\
\hline No & \\
\hline
\end{tabular}

\section{If no, then please skip to question 30}

29. If you do dry your equipment, how frequently?

\begin{tabular}{|l|l|}
\hline After every trip & \\
\hline After $2-5$ trips & \\
\hline After 6 - 10 trips & \\
After $11+$ trips & \\
\hline
\end{tabular}

\section{Bait}

30. Do you ever use live bait ?

\begin{tabular}{|l|l|}
\hline Yes & \\
\hline No & \\
\hline
\end{tabular}

If no, please move to question 34

31. What type of bait do you use?

\begin{tabular}{|l|l|}
\hline Fish & \\
\hline Maggots & \\
\hline Worms & \\
\hline Other (please state) & \\
\hline
\end{tabular}

32. Where do you source your bait from?

\begin{tabular}{|l|l|}
\hline Angling shop & \\
\hline Collect from the wild & \\
\hline Other (please state) & \\
\hline
\end{tabular}


33. What do you do with your bait at the end of your angling trip? (Choose all that apply)

\begin{tabular}{|l|l|}
\hline Take it home and keep for next trip & \\
\hline Take it home to dispose of it & \\
\hline Leave at the water body & \\
\hline Give to other anglers nearby & \\
\hline Other (please state) & \\
\hline
\end{tabular}

\section{The Check, Clean Dry Campaign}

34. Have you heard of the Check, Clean Dry campaign in the UK?

\begin{tabular}{|l|l|}
\hline Yes & \\
\hline No & \\
\hline
\end{tabular}

If no, please move onto question 36

35. If yes, where did you hear about it?

\section{Invasive Non-native Species}

36. Have you heard of invasive species?

\begin{tabular}{|l|l|}
\hline Yes & \\
\hline No & \\
\hline
\end{tabular}

If no, then please move onto question 38

37. Please list any invasive species that you can name

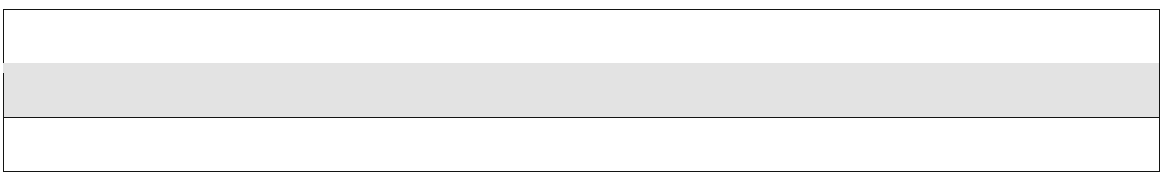

\section{Conservation Organisations}

38. Are you part of any conservation organisations?

\begin{tabular}{|l|l|}
\hline Yes & \\
\hline No & \\
\hline
\end{tabular}


39. If yes, which organisations

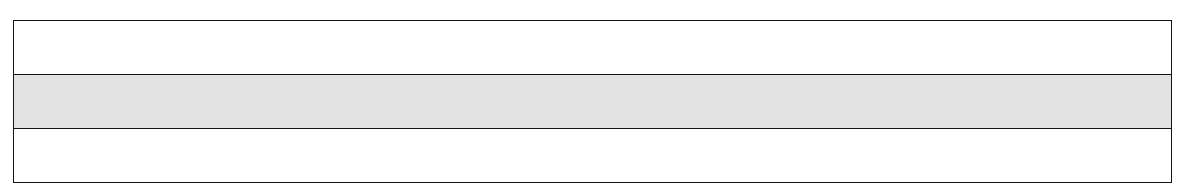

40. Are you a member of any angling clubs or syndicates?

\begin{tabular}{|l|l|}
\hline Yes & \\
\hline No & \\
\hline
\end{tabular}

41. Can you please list these clubs/syndicates

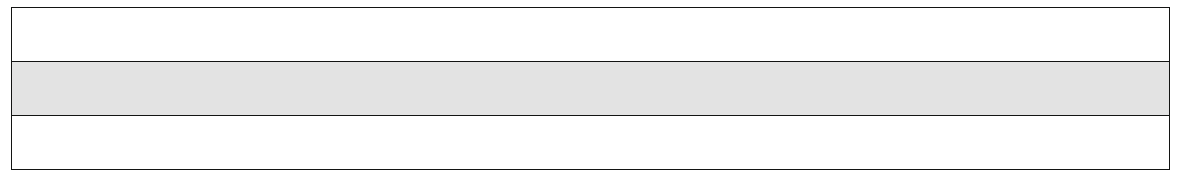

You have now reached the end of the questionnaire. Thank-you for participating.

If you have any comments or questions about anything you have come across in this survey, please contact Emily Smith at Emily.smith@anglingtrust.net

\section{References}

Anderson LG (2015) Managing aquatic non-native species: the role of biosecurity. Ph.D. Dissertation, University of Leeds, Leeds

Anderson LG, White PCL, Stebbing PD, Stentiford GD, Dunn AM (2014) Biosecurity and vector behaviour: evaluating the potential threat posed by anglers and canoeists as pathways for the spread of invasive non-native species and pathogens. PLoS ONE 9:1-10

Anderson LG, Dunn AM, Rosewarne PJ, Stebbing PD (2015) Invaders in hot water: a simple decontamination method to prevent the accidental spread of aquatic invasive non-native species. Biol Invasions 17:2287-2297

Angelsen A, Lund JF (2011) Designing the household questionnaire. In: Angelsen A, Larsen HO, Lund JF, Smith-Hull $\mathrm{C}$, Wunder S (eds) Measuring livelihoods and environmental dependence: methods for research and fieldwork. Earthscan, London, pp 107-126

Bacela-Spychalska K, Grabowski M, Rewicz T, Konopacka A, Wattier R (2013) The killer shrimp Dikerogammarus villosus (Crustacea, Amphipoda) invading alpine lakes: overland transport by recreational boats and scuba-diving gear as potential entry vectors? Aquat Conserv 23:606-618

Beninde J, Fischer ML, Hochkirch A, Zink A (2014) Ambitious advances of the European Union in the legislation of invasive alien species. Conserv Lett 49:1-17

Beyer J, Moy P, Stasio B (2010) Acute upper thermal limits of three aquatic invasive invertebrates: hot water treatment to prevent upstream transport of invasive species. Environ Manag 47:67-76

Brace I (2008) Questionnaire design: how to plan, structure and write survey material for effective market research. Kogan Page Publishers, London
Bremner A, Park K (2007) Public attitudes to the management of invasive non-native species in Scotland. Biol Conserv 139:306-314

Bruckerhoff L, Havel J, Knight S (2015) Survival of invasive aquatic plants after air exposure and implications for dispersal by recreational boats. Hydrobiologia 746:113-121

Brundu G (2015) Plant invaders in European and Mediterranean inland waters: profiles, distribution, and threats. Hydrobiologia 1:61-79

Caffrey JM, Baars J-R, Barbour JH, Boets P, Boon P, Davenport K, Dick JTA, Early J, Edsman L, Gallagher C, Gross J, Heiniman P, Horrill C, Hudin S, Hulme PE, Hynes S, MacIsaac HJ, Mcloone P, Millane M, Moen TL, Newman J, O’Conchuir R, O’Farrell M, O'Flynn C, Oidtmann B, Renals T, Riccardi A, Roy H, Shaw R, Weyl O, Williams F, Lucy FE (2014) Tackling invasive alien species in Europe: the top 20 issues. Manag Biol Invasions 5:1-20. https://doi. org/10.3391/mbi.2014.5.1.01

Caplat P, Coutts SR (2011) Integrating ecological knowledge, public perception and urgency of action into invasive species management. Environ Manag 48:878

Cerri J, Ciappelli A, Lenuzza A, Nocita A, Zaccaroni M (2017) The randomised response technique: a valuable approach to monitor pathways of aquatic biological invasions. Fish Manag Ecol 24:504-511

Cliff N, Campbell ML (2012) Perception as a tool to inform aquatic biosecurity risk assessments. Aquat Invasions $7: 387-404$

Coughlan NE, Cuthbert RN, Kelly TC, Jansen MAK (2018) Parched plants: viability of invasive aquatic macrophytes following exposure to various desiccation regimes. Aquat Bot 150:9-15

Couper MP, Miller PV (2008) Web survey methods introduction. Public Opin Q 72:831-835 
Couper MP, Kapteyn A, Schonlau M, Winter J (2007) Noncoverage and nonresponse in an internet survey. Soc Sci Res 36:131-148

Crooks JA, Soulé ME, Sandlund OT (1999) Lag times in population explosions of invasive species: causes and implications. Invasive Species Biodivers Manag 103:125

Cuthbert RN, Crane K, Caffrey JM, MacIssac HJ (2018) A dib or a dab: assessing the efficacy of Virasure ${ }^{\circledR}$ Aquatic disinfectant to reduce secondary spread of the invasive curly waterweed Lagarosiphon major. Manag Biol Invasions 9:3. https://doi.org/10.3391/mbi.2018.9.3.08

Davis AJS, Darling JA (2017) Recreational freshwater fishing drives non-native aquatic species richness patterns at a continental scale. Divers Distrib 23:692-702

De Ventura L, Weissert N, Tobias R, Kopp K, Jokela J (2017) Identifying target factors for interventions to increase boat cleaning in order to prevent spread of invasive species. Manag Biol Invasions 8:71-84

Dobson A, Barker K, Taylor SL (2013) Biosecurity: the sociopolitics of invasive species and infectious diseases. Routledge, London

Drake DAR, Mandrak NE (2014) Ecological risk of live bait fisheries: a new angle on selective fishing. Fisheries 39:201-211

Dunn AM, Hatcher MJ (2015) Parasites and biological invasions: parallels, interactions, and control. Trends Parasitol 31:189-199

EA (2004) Our nations' fisheries: the migratory and freshwater fisheries of England and Wales-a snapshot. Bristol, Environment Agency

Essl F, Bacher S, Blackburn TM, Booy O, Brundu G, Brunel S, Cardoso AC, Eschen R, Gallardo B, Galil B, García-Berthou $\mathrm{E}$ (2015) Crossing frontiers in tackling pathways of biological invasions. Bioscience 65:769-782. https://doi. org/10.1093/biosci/biv082

Fielding N (2011) Dikerogammarus villosus: preliminary trials on resistance to control measures. Freshw Biol Assoc Newslett 54

Finnoff D, Shogren JF, Leung B, Lodge D (2007) Take a risk: preferring prevention over control of biological invaders. Ecol Econ 62:216-222

Forsman A (2014) Effects of genotypic and phenotypic variation on establishment are important for conservation, invasion, and infection biology. PNAS 11:302-307

Gaddis SE (1998) How to design online surveys. Train Dev J 52:67-71

Gallardo B, Aldridge DC (2013a) Priority setting for invasive species management of Ponto-Caspian invasive species into Great Britain. Ecol Appl 23:352-364

Gallardo B, Aldridge DC (2013b) The dirty dozen: socio-economic factors amplify the invasion potential of 12 high risk aquatic invasive species in Great Britain and Ireland. J Appl Ecol 50:757-766

Gallardo B, Aldridge DC (2015) Is Great Britain heading for a Ponto-Caspian invasional meltdown. J Appl Ecol 23:352-364

Gallardo B, Clavero M, Sánchez MI, Vilà M (2016) Global ecological impacts of invasive species in aquatic ecosystems. Glob Chang Biol 22:151-163

Garcia-Llorente M, Martín-López B, González JA, Alcorlo P, Montes C (2008) Social perceptions of the impacts and benefits of invasive alien species: implications for management. Biol Conserv 141:2969-2983

Gates KK, Guy CS, Zale AV, Horton TB (2009) Angler awareness of aquatic nuisance species and potential transport mechanisms. Fish Manag Ecol 16:448-456

Genovesi P, Shine C (2004) European strategy on invasive alien Species: convention on the conservation of european wildlife and habitats (Bern Convention). CoC, Strasbourg. https://www.cbd.int/doc/external/cop-09/bern-01-en.pdf. Accessed 29 July 2018

Gozlan RE, Burnard D, Andreou D, Britton JR (2013) Understanding the threats posed by non-native species: public vs. conservation managers. PLoS ONE 8:e53200. https://doi. org/10.1371/journal.pone.0053200

Harrower CA, Scalera R, Pagad S, Schonrogge K, Roy HE (2018) Guidance for the interpretation of CBD categories on introduction pathways. IUCN, Gland

Havel JE, Shurin JB (2004) Mechanisms, effects, and scales of dispersal in freshwater zooplankton. Limnol Oceanogr 49:1229-1238

Hickley P (2018) Recreational fisheries-social, economic and management. In: Hickley P, Tompkins H (eds) Recreational fishieres: social, economic and management aspects. Wiley, Oxford

Holdich DM, Sibley P, Peay S (2004) The White-clawed crayfish-a decade on. Br Wildl 15:153-164

Hulme PE (2009) Trade, transport and trouble: managing invasive species pathways in an era of globalization. J Appl Ecol 46:10-18

Hulme PE (2015) Invasion pathways at a crossroad: policy and research challenges for managing alien species introductions. J Appl Ecol 52:1418-1424

Hussner A (2009) Growth and photosynthesis of four invasive aquatic plant species in Europe. Weed Res 49:506-515

Jaeger TF (2008) Categorical data analysis: away from ANOVAs (transformation or not) and towards Logit Mixed Models. J Mem Lang 59:434-446

Keller RP, Cox AN, Van Loon C, Lodge DM, Herborg LM, Rothlisberger J (2007) From bait shops to the forest floor: earthworm use and disposal by anglers. Am Midl Nat 158:321-328

Kilian JV, Klauda RJ, Widman S, Kashiwagi M, Bourquin R, Weglein D, Schuster J (2012) An assessment of a bait industry and angler behaviour as a vector of invasive species. Biol Invasions 14:1469-1481

Kolar CS, Lodge DM (2001) Progress in invasion biology: predicting invaders. Trends Ecol Evol 16:199-204

Lajunen T, Summala H (2003) Can we trust self-reports of driving? Effects of impression management on driver behaviour questionnaire responses. Transp Res Part F 6:97-107

Lavergne S, Molofsky J (2007) Increased genetic variation and evolutionary potential drive the success of invasive grass. PNAS 104:3883-3888

Leung B, Lodge DM, Finnoff D, Shogren JF, Lewis MA, Lamberti G (2002) An ounce of prevention or a pound of cure: bioeconomic risk analysis of invasive species. Proc $\mathrm{R}$ Soc Lond (Biol) 269:2407-2413

Longhurst R (2010) Semi-structured interviews and focus groups. In: Clifford N, French S, Valentine G (eds) Key methods in geography. SAGE, London, pp 103-115 
Mack R, Simberloff D, Lonsdale WM, Evans H, Clout M, Bazzaz FA (2000) Biotic invasions: causes, epidemiology, global consequences, and control. Ecol Appl 10:689-710

Maitland PS (1987) Fish introductions and translocations - their impact in the British Isles. In: Maitland PS, Turner AK (eds) Angling and wildlife in fresh waters. ITE Symposium, pp 57-65

Okada M, Grewell BJ, Jasieniuk M (2009) Clonal spread of invasive Ludwigia hexapetala and L. grandiflora in freshwater wetlands of California. Aquat Bot 91:123-129

Peeler EJ, Gardiner RR, Thrush MA (2004) Qualitative risk assessment of routes of transmission of the exotic fish parasite Gyrodactylus salaris between river catchments in England and Wales. Prev Vet Med 64:175-189

Perepelizin PV, Boltovskoy D (2011) Hot water treatment (chronic upper lethal temperature) mitigates biofouling by the invasive asian mussel Limnoperna fortunei in industrial installations. Environ Sci Technol 45:7868-7873

Pigneur LM, Marescaux J, Roland K, Etoundi E, Descy JP, Van Doninck K (2011) Phylogeny and androgenesis in the invasive Corbicula clams (Bivalvia, Corbiculidae) in Western Europe. BMC Evol Biol 11:147-163

Pitcher TJ, Hollingworth C (2002) Recreational fisheries: ecological, economic and social evaluation. Blackwell Science, London

Prinbeck G, Lach D, Chan S (2011) Exploring stakeholders' attitudes and beliefs regarding behaviors that prevent the spread of invasive species. Environ Educ Res 17:341-352

Pyšek P, Jarošík V, Pergl J (2011) Alien plants introduced by different pathways differ in invasion success: unintentional introductions as a threat to natural areas. PLoS ONE 6:1-11

Rahel FJ, Olden JD (2008) Assessing the effects of climate change on aquatic invasive species. Conserv Biol 22:521-533

Randall DM, Fernandes MF (1991) The social desirability response bias in ethics research. J Bus Ethics 10:805-817

Ricciardi A (2015) Ecology of invasive alien invertebrates. In: Thorp JH, Rogers DC (eds) Ecology and general biology: freshwater invertebrates. Academic Press, Cambridge, pp 83-91

Rogers EM (2003) Diffusion of innovations, 5th edn. Free Press, New York

Roy HE, Peyton J, Aldridge DC, Bantock T, Blackburn TM, Britton R, Clark P, Cook E, Dehnen-Schmutz K, Dines T, Dobson M, Edwards F, Harrower C, Harvey MC, Minchin D, Noble DG, Parrott D, Pocock MJO, Preston CD, Roy S, Salisbury A, Schönrogge K, Sewell J, Shaw RH, Stebbing P, Stewart AJA, Walker KJ (2014) Horizon scanning for invasive alien species with the potential to threaten biodiversity in Great Britain. Glob Change Biol 20:3859-3871

Schmidt WC (1997) World-Wide Web survey research: benefits, potential problems, and solutions. Behav Res Methods Instrum Comp 29:274-279

Sebire M, Rimmer G, Hicks R, Parker SJ, Stebbing PD (2018) A preliminary investigation into biosecurity treatments to manage the invasive killer shrimp (Dikerogammarus villosus). Manag Biol Invasions 9:101-113
Shannon C, Quinn CH, Stebbing PD, Hassal C, Dunn A (2018) The application of hot water to reduce the introduction and spread of aquatic invasive alien species. Manag Biol Invasions 9:417-423

Simberloff D, Martin J-L, Genovesi P, Maris V, Wardle DA, Aronson J, Courchamp F, Galil B, Garcia-Berthou E, Pascal M, Pysek P, Sousa R, Tabacchi E, Vila M (2013) Impacts of biological invasions: what's what and the way forward. Trends Ecol Evol 28:58-66

Simpson D, Mawle GW (2010) Public attitudes to angling 2010. Bristol, Environment Agency

Sports England (2011) Fishing for answers: final report of the social and community benefits of angling project. Substance, Bristol

Stebbing PB, Sebire M, Lyons B (2011) Evaluation of a number of treatments to be used as biosecurity measures in controlling the spread of the invasive killer shrimp (Dikerogammarus villosus)_final report. Lowestoft, Cefas

Suarez AV, Holway DA, Case TJ (2001) Patterns of spread in biological invasions dominated by long-distance jump dispersal: insights from Argentine ants. PNAS 98:1095-1100

Sutcliffe C, Quinn CH, Shannon C, Glover A, Dunn AM (2018) Exploring the attitudes to and uptake of biosecurity practices for invasive non-native species: views amongst stakeholder organisations working in UK natural environments. Biol Invasions 20:399-411

Trouwborst A (2015) The Bern convention and EU regulation $1143 / 2014$ on the prevention and management of the introduction and spread of invasive alien species. https:// papers.ssrn.com/sol3/papers.cfm?abstract_id=2623496. Accessed 26 July 2018

von Brandt A (1964) Modern fishing of the world 2. Fishing News Books Ltd, London

White PCL, Jennings NV, Renwick AR, Barker NHL (2005) Questionnaires in ecology: a review of past use and recommendations for best practice. J Appl Ecol 42:421-430

Williams AE, Moss B (2001) Angling and conservation at sites of special scientific interest in England: economics, attitudes and impacts. Aquat Conserv 11:357-372

Winfield IJ, Adams CE, Fletcher JM (1996) Recent introductions of the ruffe (Gymnocephalus cernuus) to three United Kingdom lakes containing Coregonus species. Ann Zool Fenn 33:459-466

Wittenberg R, Cock MJW (2001) Invasive alien species: a toolkit of best prevention and management practices. CABI, Wallingford

Zięba G, Copp GH, Davies GD, Stebbing PD, Wesley KJ, Britton JR (2010) Recent releases and dispersal of nonnative fishes in England and Wales, with emphasis on sunbleak Leucaspius delineatus. Aquat Invasions 5:155-161

Publisher's Note Springer Nature remains neutral with regard to jurisdictional claims in published maps and institutional affiliations. 